\title{
The influence of the family environment and parental education level through parental attachment to children's cognitive development
}

\author{
Nurilla Santi *, Muhammad Saleh, Aslamiah \\ Master Program of Early Childhood Teacher Education, Universitas Lambung Mangkurat, Banjarmasin \\ 70123, Indonesia
}

Article history:

Submission October 2020

Revised December 2020

Accepted January 2021

${ }^{*}$ Corresponding author:

E-mail: nurillasanti456@gmail.com

\begin{abstract}
The importance of family support, parental education, and parental attachment are expected to contribute to the development of children's cognitive aspects. The research objective is to determine the effect of family environment and parental education level through parental attachment to children's cognitive development. This research uses quantitative with the explanatory method, namely cause, and effect. This research population is 415 , with a sample of 204 people selected by the proportional sampling technique. The research used a questionnaire to collect the data. Data analysis used regression analysis and path analysis. The results show an effect of the family environment on children's cognitive development of 0.248 . The level of education of parents is 4,587. Parent attachment is 0.333 . There is an effect of the family environment on the attachment of people of 0.459 . The level of parental education on parental attachment is 7,682. There is an indirect effect of the family environment through the parental attachment of 0.031 . There is an indirect effect of parental education level through parental attachment to the cognitive development of 0.641 . It is suggested that parents understand well how to educate their children so that they can provide independence to children and understand themselves in the future.
\end{abstract}

Keywords: Family environment, parental education level, parental attachment, cognitive development

\section{Introduction}

Education is an essential thing in everyone's life. In Indonesia, education is a right for all Indonesian citizens. Education provides us with knowledge on how to behave, speak, and learn about scientific developments, which can be used for many audiences. Education is to create someone of quality and character so that they have a broad view of the future to achieve the expected goals and adapt quickly and precisely in various environments.

Various kinds of development need to be given to children from all aspects that can be developed in children. According to Nasution, there are three aspects of children's learning abilities: affective, psychomotor, and cognitive skills (Chatib, 2014). One of the learning abilities discussed here is cognitive abilities in children. Children's cognitive abilities will develop if the child is given stimulation from the environment; this requires parents' and educators' role in its implementation (Patrikakou, 2015; Karibayeva \& Bogar, 2014). Collaboration between educators and parents is needed to develop children's cognitive abilities (Blandul, 2012). In addition to natural development, children also need guidance, direction, and motivation from the environment in developing skills in children (Çevik, 2017). This is in line with Vygotsky's opinion, which states that cognitive abilities and thought patterns are not based on innate factors but result from activities or the 
environment in which the individual lives (Sujiono, 2013).

The aspect of cognitive development is one aspect that needs to be developed, and this is also the goal of learning in kindergarten. This cognitive ability contains the reason, thoughts, humans who can distinguish what is right or wrong, which should be done or avoided, how to act, and so on, which in essence a person can solve problems in his life (Arifin et al., 2019). Therefore, cognitive abilities are essential for a person's life and need to be provided and developed as early as possible (Carson et al., 2015).

In early childhood, it is necessary to have the right stimulus or stimulation to create optimal growth and development of children (Wang \& wang, 2015; Jin et al., 2020; Purwanti et al., 2018). Cognitive development refers to changes in thought processes throughout a child's life cycle from conception to age eight. Cognitive development is closely related to logos-mathematical and naturalist intelligence (Rohmah \& Waluyo, 2014). The logical-mathematical intelligence stimulus will encourage cognitive development, especially in terms of thinking logically, process information, thinking capacity, memorization, reasoning, concept acquisition, classification, problem-solving, and concentration (Musfiroh, 2012).

This is following Gardner's opinion, which states that intelligence is the ability to solve problems or create works valued in a culture or more (Gardner, 2011). Kartadinata states that brain development and children's brain structure continue to grow after birth (Susanto, 2015). Several studies have shown that early childhood experiences, the imagination that occurs, the language heard, the books showed will help form brain networks (Dawson et al., 2000; Tierney \& Nelson, 2009). Thus, through cognitive development, thought functions can be used quickly and precisely to solve a situation to solve a problem. The cognition process includes various aspects, such as perception, memory, thoughts, symbols, reasoning, and problem-solving (Wang \& Chiew, 2010). Associated with cognitive learning, children are expected to think logically, critically, give reasons, solve problems, and find causal relationships.
One of the efforts to develop children's cognitive is by providing learning that can hone children's logic-math intelligence (Nur, Herman, \& Mariyana, 2018). In the development of cognitive aspects in kindergarten, numbers are a concept that is learned. The importance of numbers is given at kindergarten age because the concept of numbers is one of the concepts children learn when they are at a higher level of education (Bidzan-Bluma \& Lipowska, 2018; Riyanti et al., 2018). Besides, the importance of numbers is taught to kindergarten children to foster children's love and preference for numbers (Yilmaz, 2017; Aunio et al., 2015). Moreover, numbers are one concept that is not separate from everyday life (Alomyan et al., 2020).

Teachers and parents' role is very important in children's development, especially in understanding the child's golden period as early as possible (Amalia \& Khoiriyati, 2018; Alpiyanto et al., 2012). When conducting this research, the teacher found many benefits, including the teacher understanding that children will be more active when children are directly involved in these activities. The use of interesting media will foster children's attention by directly training them to gain their own experience.

Early childhood education teachers should provide the students with well-scaffolded instruction to support the students' social development, emotional, academic, habits, and mindsets (Darling-Hammond et al., 2020). A teacher is expected to provide an excellent environment to foster student development optimally in the learning process (Suriansyah et al., 2009).

How to learn early childhood is different from the way of learning adults and older children, namely through playing and using media tools such as touching, building and breaking down, filling and emptying, stringing, listening to stories and singing, playing roles, and so on (Wahyudi, 2015). Learning in kindergarten is carried out with the principle of "learning while playing" following the development of students this is because, at the age of 4-6 years, children are still in playtime, so that all activities carried out in kindergarten prioritize play activities (Aslamiah, 2011). With learning activities 
while playing, students are expected to be able to develop all their abilities.

One of the reasons for developing cognitive abilities is the family environment because a good family environment will make children more able to think and be able to understand all the problems they face so far. Indeed, the family is the first stage of institutions of social importance and to a very high degree; it is closely related to civilization, the transformation of heritage, and the growth and development of mankind.

The role of the family environment is one of the pillars in the three education centers. The family environment is the central pillar for shaping the human person's pros and cons to develop well in ethics, morals, and morals. The role of the family can shape children's attitudes and personal patterns. It can also determine the educational process that children get, not only in school but also in all factors that can be used as sources of education. The family environment can also play a role as a source of children's knowledge. It can also affect the success of student achievement (Hasbullah, 2013). Children in the womb to old age or burrow will get an education, both from the family environment (informal education), the school environment (formal education), and the community environment (non-formal). The family environment must provide and prepare the education for their children to become educated future generations, namely through educational levels so that the personal development of children with good character, social spirit, civilized behavior, and skilled in their skills. The family environment is an exemplary example of the early formation of a child's personality and character, especially those related to children's cognitive development.

Things that can influence children's cognitive development are in terms of the educational background of the parents. This is following Haditono's statement that the environment closest to the child is the family. The background factor of the level of parental education has a big influence on the child's development (Haditono \& Rahayu, 2011). The background of the level of parental education is significantly correlated with how they care for their chil- dren. At the same time, parenting has a relationship with the level of child development, and the development of the child will later influence learning achievement at school. This means that the higher the parents' last education, the better the way of caring for the child, and as a result, the child's development is affected positively.

Conversely, the lower the level of parental education, the less good it will be in caring for children so that the child's development is less profitable (Sulistyanngsih, 2014). The simple concept of family is where children and parents interact and learn from the beginning of the child's birth to the end. The learning capital obtained will be used as provisions for children's lives in the future and to foster self-confidence among others.

Wulandari, who revealed that the primary function clearly in a family is an activity that is used as a vehicle, a home, and also a place to learn to live life, and also for the process of developing one's abilities and potential in various ways, doing exercises and trying to create sense compassion, which is no less important is to practice building self-confidence in each other (Wulandari \& Surjono, 2013). The family's core concept is the level of parental education, where the most crucial role is the mother. Therefore, a mother is one of the essential factors in creating mental and educating children in the family environment because the mother is the first environment experienced by children in conducting socialization.

Apart from the family environment and parental education that can influence the child's cognitive development, parents' attachment to children to guide children. Attachment is a strong emotional bond developed by children through their interactions with people who have special meaning in their lives (Suwarjo \& Eliasa, 2011). Most children have formed an attachment to the primary caregiver at the age of about eight months with the proportion of $50 \%$ to mothers, $33 \%$ to fathers, and the rest to others (Sutcliffe, 2012). Attachment is not a bond that occurs naturally. There is a series of processes that must be passed to form this attachment. According to Jacobson and Hoffman, if children get a secure foundation and can trust 
their parents' responses, they will feel confident enough to actively involve themselves in their world (Papalia \& Feldman, 2015). Children with unsafe attachment tend to show negative emotions (fear, distress, and anger), while children with safe attachment look more cheerful. Between the ages of 3 and 5, children with a secure attachment will grow more curious, competent, empathetic, resilient, and confident, get along better with other children, and form close friendships than children with unsafe attachment. They interact more positively with parents, teachers, and peers and can better resolve conflicts.

Based on the description above, attachment between parents and children has a significant impact on children's future behavior. If the child has a good attachment or secure attachment with his parents, it is believed that the child will develop more optimally and have positive behavior. This allows for a relationship between parent-child attachment with children's intelligence in learning, especially in developing children's cognitive abilities. This study aimed to determine the effect of family environment and parental education level through parental attachment to children's cognitive development.

\section{Material and Methods}

This type of research uses a quantitative research approach. The method used is descriptive with associative techniques (correlational). This study is intended to determine the relationship between the family environment variable (X1), parent education variable (X2) as the independent variable $(\mathrm{Z})$ parental attachment as $(Y)$ variable related to children's cognitive development.

This research population is the parents of the children of Gugus Anggrek Kindergarten in West Banjarmasin District, amounting to 415 with the sampling using a proportional technique with a sample of 204 people. Data collection techniques in the form of observation, direct interviews, questionnaires, measurements/ checks.

The research instrument was a closed questionnaire using a Likert scale model made in the form of a checklist and data analysis using regression analysis and path analysis.

\section{Results and Discussion}

Based on the results of research from the child's parents who were given the questionnaire, it is described as follows:

\section{The effect of family environment on chil- dren's cognitive development}

The regression test results on the Family Environment on the Cognitive Development of Kindergarten Children with Orchid Clusters DI West Banjarmasin District, then from the significant level is $0.000<0.05$. The regression result or positive influence is $\mathrm{Y}=51,916+0.248 \mathrm{X} 1=52,164$. Then the results show that with this positive value, the level of trust increases so that it can be concluded that the family environment has a positive value on children's cognitive development so that they can perform their abilities. They can understand the lessons given either at school or at home.

The $\mathrm{r}$ square analysis results showed that $0.156=15.6 \%$ had an effect on the Family Environment on Cognitive Development of Kindergarten Children with Orchid Clusters in West Banjarmasin District. A similar finding was also found by $\mathrm{Su}$ et al. (2020) and Kreiner \& Sievertsen (2020) that the family environment significantly influences young learners' cognitive development.

\section{The effect of parents' education level on chil- dren's cognitive development}

The effect of parenting on parental education level on children's cognitive development with a significant level of results is $0.000<0.05$. The results of the level of education show that 4,587 affect children's cognitive development.

The regression results or positive influence, namely $\mathrm{Y}=61,971+4,587 \mathrm{X} 1=66,558$. The results show that with this positive value, the higher the parental education, the better the level of trust, so it can be concluded that parental education will provide a positive value on children's cognitive development. It can make them better able to provide education so that the cognitive aspects of their children can develop properly.

The $r$ square analysis results show that 0.140 $=14 \%$ affects the level of parental education on 
children's cognitive development. The research results showed that Ho was rejected, meaning that there was an effect on the level of parental education on the cognitive development of the Gugus Anggrek Kindergarten children in West Banjarmasin District. This study's result is supported by the previous studies conducted by Gonzalez et al. (2020) and Halim et al. (2018). They found that parental education significantly influences young learners' cognitive development.

\section{Direct effect of parental attachment on chil- dren's cognitive development}

The influence of parents' role on the Direct Effect of Parental Attachment on Cognitive Development of Kindergarten Children with Orchid Clusters in West Banjarmasin District with a significant level is $0.000<0.05$. The regression results or positive influence, namely $\mathrm{Y}=51,223+$ $0.333 \mathrm{X} 1=51,556$, the results show that with this positive value, the level of trust increases so that it can be concluded the better the parental attachment, the better the child's cognitive development. The $r$ square analysis results showed that $0.148=$ $14.8 \%$ had a direct effect on parental attachment on children's cognitive development. Ho is rejected, meaning that there is a direct effect of parental attachment on children's cognitive development.

\section{The influence of the family environment on the attachment of the child's parents}

The family environment's effect on the attachment of parents of Kindergarten children at Gugus Anggrek Kindergarten in West Banjarmasin District. The result of the significant level is 0.000 $<0.05$. The regression results or positive influence, namely $Y=26,506+0.459=26,965$, then the results show that with this positive value, the level of trust increases so that it can be concluded that the family environment will provide a positive value on parental attachment in providing education to their children. The $\mathrm{r}$ square analysis results showed that $0.399=39.9 \%$ had an effect on the family environment on the attachment of parents of Kindergarten children at Gugus Anggrek Kindergarten in West Banjarmasin District.

The influence of the level of parental education on the attachment of the child's parents
The influence of parental education on the attachment of parents of Kindergarten children at Gugus Anggrek Kindergarten in West Banjarmasin District with the result of the significant level is $0.000<0.05$. The regression results or positive influence, namely $\mathrm{Y}=47,054+7,682=54,736$, show that with this positive value, the high level of parental education can provide better results so that parents' attachment to children is even better.

The results of the $r$ square analysis showed that $0.294=29.4 \%$ had an influence on the level of parental education on the attachment of parents of Kindergarten children at Gugus Anggrek Kindergarten in West Banjarmasin District, because this value was still small, meaning that other variables affected parental attachment to the child.

\section{The indirect influence of the family environ- ment through parental attachment to chil- dren's cognitive development}

The indirect effect of the family environment through the parental attachment on the cognitive development of the Gugus Anggrek Kindergarten children in West Banjarmasin District. The results of the path analysis show that the results of the contribution level of the path analysis of the direct relationship of the family environment through parental attachment to cognitive development with the value of Standardized Coefficients beta of 0.159 with the family environment through parental attachment to cognitive development is 0.195 , so it can be seen that the level of the relationship is not The direct relationship is $0.159 \times 0.195=$ 0.031 , so the positive indirect relationship of the family environment through parental attachment to cognitive development is 0.031 . The result of the sig level of each variable is $0.000<0.05$. This means that Ho is rejected, which means an indirect relationship between the family environment through parental attachment to children's cognitive development.

The result of the significant level of the $\mathrm{F}$ test is $0.000<0.05$. The $r$ square analysis results show that $0.186=18.6 \%$ of the family environment through parental attachment to the cognitive development of children at Gugus Anggrek Kindergarten in West Banjarmasin District. Based on these results, it shows that there are still other variables that have an effect of $100 \%$ of $82.4 \%$, which influence children's cognitive development, apart 
from the family environment through parental attachment to TK Gugus Anggrek in West Banjarmasin District.

The indirect influence of parental education level through parental attachment to children's cognitive development

The indirect effect of parental education level through parental attachment to the cognitive development of the Gugus Anggrek Kindergarten children in West Banjarmasin District. The path analysis results indicate that the results of the significant level of the $F$ test are $0.000<0.05$. The contribution level from the path analysis of the indirect relationship between the level of parental education through parental attachment to cognitive development with the value of Standardized Coefficients beta of 2.875 with the level of parental education through parental attachment to cognitive development is 0.223 . It can be seen that the level of the indirect relationship. If this is $2.875 \mathrm{x}$
$0.223=0.641$, then the indirect positive relationship between parental education level through parental attachment to cognitive development is 0.641 . The result of the sig level of each variable is $0.000<0.05$. This means that Ho is rejected, which means that there is an indirect relationship between parental education level through parental attachment to cognitive development.

The $\mathrm{r}$ square analysis results showed that $0.187=18.7 \%$ affected parental education level through parental attachment to cognitive development. The path analysis results indicate that it means that other variables influence the cognitive development of the Gugus Anggrek Kindergarten children in West Banjarmasin District. The results showed that the level of influence indicated that there were still other variables that affected $100 \%$. There was $81.3 \%$ in addition to the variables of parental education level and parental attachment.

Data collection uses questionnaires and observation methods. Hypothesis testing using Path Analysis is assisted by SPSS 23 application.

Table 1 . The results of the test on the effect of the family environment on cognitive development

\section{Coefficients}

\begin{tabular}{lrrrrrr}
\hline \multicolumn{5}{c}{ Unstandardized Coef- Standardized Coeffi- } \\
ficients & cients & & \\
Model & B & Std. Error & Beta & \multicolumn{1}{c}{ t } & \multicolumn{1}{c}{ Sig. } \\
\hline 1 (Constant) & 51.916 & 3.498 & & & 14.840 & .000 \\
\multicolumn{1}{l}{ Family Environment (X1) } & .248 & .041 & & .395 & 6.106 & .000 \\
\hline
\end{tabular}

a. Dependent Variable: Cognitive Development Anak (Y)

Tabel 2. Model summary

\begin{tabular}{lrrrr}
\hline Model & R & R Square & Adjusted R Square & \multicolumn{2}{c}{ Std. Error of the Estimate } \\
\hline 1 & $.395^{\mathrm{a}}$ & .156 & .152 & 6.80619
\end{tabular}

a. Predictors: (Constant), Family Environment (X1)

Table 3. The results of the test on the effect of parental education level on cognitive development

\section{Coefficients ${ }^{\mathbf{a}}$}

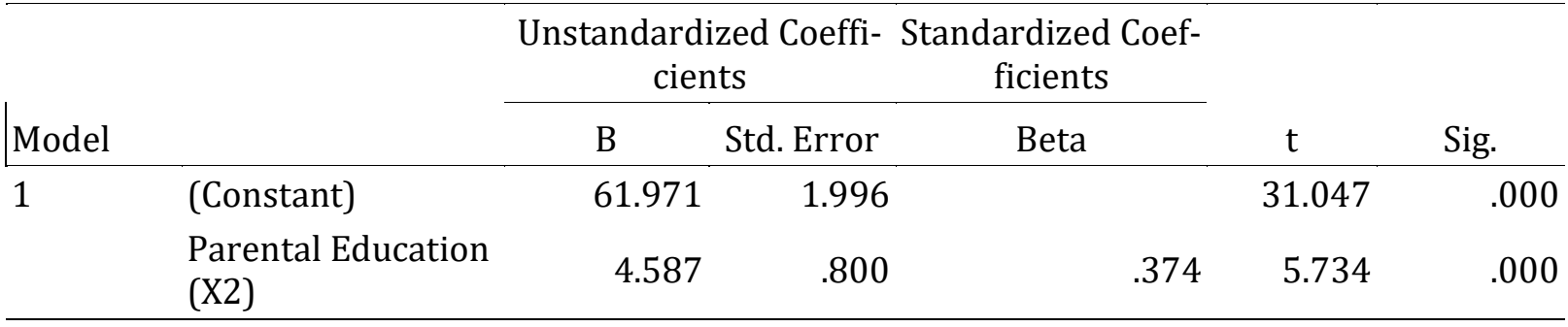

a. Dependent Variable: Child Cognitive Development (Y) 
Table 4. Model summary

\begin{tabular}{lllll} 
Model & $\mathrm{R}$ & R Square & Adjusted R Square & $\begin{array}{l}\text { Std. Error of the } \\
\text { Estimate }\end{array}$ \\
\hline 1 & $.374^{\mathrm{a}}$ & .140 & .136 & 6.86981 \\
\hline
\end{tabular}

a. Predictors: (Constant), Parental Education (X2)

Table 5. The test results of the direct effect of parental attachment on cognitive development

Coefficients $^{\mathbf{a}}$

\begin{tabular}{|c|c|c|c|c|c|c|}
\hline \multirow[b]{2}{*}{ Model } & & \multicolumn{2}{|c|}{$\begin{array}{l}\text { Unstandardized Coeffi- } \\
\text { cients }\end{array}$} & \multirow{2}{*}{$\begin{array}{c}\text { Standardized } \\
\text { Coefficients }\end{array}$} & \multirow[b]{2}{*}{ 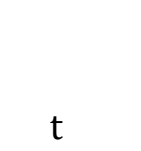 } & \multirow[b]{2}{*}{ Sig. } \\
\hline & & $\mathrm{B}$ & Std. Error & & & \\
\hline 1 & (Constant) & 51.223 & 3.720 & & 13.768 & .000 \\
\hline & $\begin{array}{l}\text { Parents Attachment } \\
\text { (X3) }\end{array}$ & .333 & .056 & .385 & 5.924 & .000 \\
\hline
\end{tabular}

a. Dependent Variable: Child Cognitive Development (Y)

Table 6. Model Summary

\begin{tabular}{lrrrr}
\hline Model & R & R Square & Adjusted R Square & Std. Error of the Estimate \\
\hline 1 & $.385^{\mathrm{a}}$ & .148 & .144 & 6.83765 \\
\hline
\end{tabular}

a. Predictors: (Constant), Parents Attachment (X3)

Table 7. Test results the effect of the family environment on parental attachment

\section{Coefficients $^{\mathrm{a}}$}

\begin{tabular}{|c|c|c|c|c|c|c|}
\hline \multirow[b]{2}{*}{ Model } & & \multicolumn{2}{|c|}{$\begin{array}{l}\text { Unstandardized Coeffi- } \\
\text { cients } \\
\end{array}$} & $\begin{array}{c}\text { Standardized } \\
\text { Coefficients } \\
\end{array}$ & \multirow[b]{2}{*}{$\tau$} & \multirow[b]{2}{*}{ Sig. } \\
\hline & & B & Std. Error & Beta & & \\
\hline 1 & (Constant) & 26.506 & 3.411 & & 7.771 & .000 \\
\hline & $\begin{array}{l}\text { Family Environ- } \\
\text { ment (X1) }\end{array}$ & .459 & .040 & .632 & 11.587 & .000 \\
\hline
\end{tabular}

a. Dependent Variable: parents Attachment (X3)

Table 8. Model summary

\begin{tabular}{lrrrr} 
Model & $\mathrm{R}$ & R Square & Adjusted R Square & Std. Error of the Estimate \\
\hline 1 & $.632^{\mathrm{a}}$ & .399 & .396 & 6.63573
\end{tabular}

a. Predictors: (Constant), Family Environment (X1)

Table 9. Test results effect of parental education level on parental attachment

\section{Coefficients $^{\mathrm{a}}$}

\begin{tabular}{|c|c|c|c|c|c|}
\hline \multirow[b]{2}{*}{ Model } & \multicolumn{2}{|c|}{$\begin{array}{l}\text { Unstandardized Coeffi- } \\
\text { cients }\end{array}$} & \multirow{2}{*}{$\frac{\begin{array}{c}\text { Standardized Co- } \\
\text { efficients }\end{array}}{\text { Beta }}$} & \multirow[b]{2}{*}{$\mathrm{t}$} & \multirow[b]{2}{*}{ Sig. } \\
\hline & B & Std. Error & & & \\
\hline 1 (Constant) & 47.054 & 2.090 & & 22.512 & .000 \\
\hline Parental Education (X2) & 7.682 & .838 & .542 & 9.170 & .000 \\
\hline
\end{tabular}

a. Dependent Variable: Parents attachment (X3) 
Table 10. Model summary

\begin{tabular}{lrrrr} 
Model & R & R Square & Adjusted R Square & Std. Error of the Estimate \\
\hline 1 & $.542^{\mathrm{a}}$ & .294 & .290 & 7.19394 \\
\hline
\end{tabular}

a. Predictors: (Constant), Parental Education (X2)

Table 11. Path analysis results of the indirect effect of the family environment through the attachment of parents to cognitive development of children

\section{Coefficients $\mathbf{a}^{\mathrm{a}}$}

\begin{tabular}{|c|c|c|c|c|c|c|}
\hline \multirow{2}{*}{\multicolumn{2}{|c|}{ Model }} & \multicolumn{2}{|c|}{$\begin{array}{l}\text { Unstandardized Co- } \\
\text { efficients }\end{array}$} & \multirow{2}{*}{$\begin{array}{c}\begin{array}{c}\text { Standardized Co- } \\
\text { efficients }\end{array} \\
\text { Beta }\end{array}$} & \multirow[b]{2}{*}{$\mathrm{t}$} & \multirow[b]{2}{*}{ Sig. } \\
\hline & & B & Std. Error & & & \\
\hline 1 & (Constant) & 46.751 & 3.924 & & 11.913 & .000 \\
\hline & Family Environment (X1) & .159 & .052 & .252 & 3.075 & .002 \\
\hline & Parents Attachment (X3) & .195 & .071 & .225 & 2.743 & .007 \\
\hline
\end{tabular}

a. Dependent Variable: Child Cognitive Development (Y)

Table 12. Results of the coefficient of determination the influence of the family environment through parental attachment against cognitive development

\begin{tabular}{lrrrr}
\hline \multicolumn{5}{c}{ Model Summary } \\
\hline Model & $\mathrm{R}$ & R Square & Adjusted R Square & Std. Error of the Estimate \\
\hline 1 & $.432^{\mathrm{a}}$ & .186 & .178 & 6.69885 \\
\hline
\end{tabular}

a. Predictors: (Constant), Parents Attachment (X3), Family Environment (X1)

Table 13 Path analysis results of the indirect effect of parental education level through parental attachment to cognitive development

\section{Coefficients ${ }^{\mathbf{a}}$}

Unstandardized Coeffi- Standardized Coeffi-

\begin{tabular}{llrrrrr} 
& & \multicolumn{2}{c}{ cients } & cients & \multicolumn{1}{c}{ t } & Sig. \\
\cline { 2 - 6 } Model & \multicolumn{1}{c}{ B } & Std. Error & Beta & & \\
\hline 1 & (Constant) & 51.484 & 3.645 & & 14.126 & .000 \\
& Parental Education (X2) & 2.875 & .928 & .234 & 3.098 & .002 \\
& Parents Attachment (X3) & .223 & .065 & .258 & 3.403 & .001 \\
\hline
\end{tabular}

a. Dependent Variable: Child Cognitive Development (Y)

Table 14. Results of the coefficient of determination The indirect effect of parental education level through parental attachment to children's cognitive development

\section{Model Summary}

\begin{tabular}{lrrrr} 
Model & R & R Square & Adjusted R Square & Std. Error of the Estimate \\
\hline 1 & $.432^{\mathrm{a}}$ & .187 & .179 & 6.69667 \\
\hline
\end{tabular}

a.Predictors: (Constant), Parents Attachment (X3), Parental Education (X2)

\section{Conclusion and Recommendation}

From the result of the study, it can be concluded that:
1. The family environment is relatively high, totaling 176 people (86.3\%). Parental edu- 
cation is varied, namely D3, D4, and S1, totaling 98 people (48\%). So far, parental attachment is relatively high, amounting to 142 people $(69.6 \%)$. So far, children's cognitive development is still relatively high, amounting to 160 people (78.4\%).

2. There is an influence of the family environment on children's cognitive development at Gugus Anggrek Kindergarten in the District of West Banjarmasin, amounting to 0.248 .

3. There is an effect of the level of parental education on the cognitive development of children ay Gugus Anggrek Kindergarten in District of West Banjarmasin amounting to 4.587.

4. There is a direct effect of parental attachment on children's cognitive development in Gugus Anggrek Kindergarten in the District of West Banjarmasin, amounting to 0.333 .

5. There is an influence of the family environment on the attachment of parents of Kindergarten children at Gugus Anggrek Kindergarten in the District of West Banjarmasin, amounting to 0.459 .

6. There is an effect of parental education on the attachment of children's parents at Gugus Anggrek Kindergarten in the District of West Banjarmasin, amounting to 7,682 .

7. There is an indirect effect of the family environment through a parental attachment on children's cognitive development at Gugus Anggrek Kindergarten in the District of West Banjarmasin, amounting to 0.031 .

8. There is an indirect effect of parental education level through a parental attachment on children's cognitive development at Gugus Anggrek Kindergarten in District of West Banjarmasin, amounting to 0.641.

Based on the research results, it is suggested that:

1. For schools, it is expected that teachers and principals can pay more attention to children's cognitive abilities so that they can better understand children's learning methods.
2. Parents should pay attention to the social behavior of children at home and not suppress children according to the wishes of the parents so that it can make children more capable and more independent in interacting with children's daily lives. This is so that children can develop their cognitive abilities in the future.

3. For further researchers as input in understanding the variables of the family environment, education, and parental attachment to children, they can develop children's abilities both from the motoric, affective, and cognitive aspects of children.

\section{Acknowledgment}

We would like to thank you for supporting this research in writing this journal article. The authors were greatly assisted by many parties, especially principals, teachers, and parents In Gugus Anggrek Kindergarten in Kecamatan Banjarmasin Barat

\section{References}

Alomyan, H., Alelaimat, A., Hamzeh, M., \& Green, D. (2020). Developing number concepts in young children through educational games. Universal Journal of Educational Research, $8(8), \quad 3323 \quad$ - 3334. doi:10.13189/ujer.2020.080804

Alpiyanto, Hamda, S., \& Dalle, J. (2012). The role of teachers in the formation of student characters through local visition. Prosiding Temu Ilmiah Nasional Guru IV (pp. 74-83). Jakarta: Open University.

Amalia, E. R., \& Khoiriyati, S. (2018). Effective learning activities to improve early childhood cognitive development. AlAthfal Jurnal Pendidikan Anak, 4(1), 103-112. doi:http://dx.doi.org/10.14421/al-athfal.2018.41-07

Arifin, S., Kartono, K., \& Hidayah, I. (2019). The analysis of problem solving ability in terms of cognitive style in problem-based learning models with diagnostic assessment. Unnes Journal of Mathematics Education Research, 8(2), 147-156.

Aslamiah. (2011). Penerapan pembiasaan perilaku anak melalui kegiatan belajar dan bermain di TK Al-hamid Banjarmasin. Jurnal Paradigma, 5(10), 33-44.

Aunio, P., Heiskari, P., Luit, J. E., \& Vuorio, J.-M. (2015). The development of early numeracy skills in kindergarten in low-, average- and high-performance groups. Journal of Early Childhood Research, 13(1), 3-16. doi:https://doi.org/10.1177/1476718X14538722 
Bidzan-Bluma, l., \& Lipowska, M. (2018). Physical activity and cognitive functioningof children: a systematic review. International Journal of Environmental Research and Public Health, 15, 1-13. doi:10.3390/ijerph15040800

Blandul, V. C. (2012). The partnership between school and family - cooperation or conflict? Procedia - Social and Behavioral Sciences, 47 , 1501-1505. doi:10.1016/j.sbspro.2012.06.850

Carson, V., Hunter, S., Kuzik, N., Wiebe, S. A., Spence, J. C., Friedman, A., Tremblay, M. S., Slater, L., \& Hinkley, T. (2015). Systematic review of physical activity and cognitive development in early childhood. Journal of Science and Medicine in Sport,19(7), 1-6. doi:http://dx.doi.org/10.1016/j.jsams.2015.07.011

Çevik, G. B. (2017). Examining pre-school teachers' and parents' views on counseling and guidance services in pre-school education. International Journal of Evaluation and Research in Education, 6(3), 207-215. doi:10.11591/ijere.v6i3.pp207-21

Chatib, M. (2014). Human teacher: making all children special and all champion children. Bandung: Mizan Pustaka.

Darling-Hammond, L., Flook, L., Cook-Harvey, C., Barron, B., \& Osher, D. (2020). Implications for educational practice of the science of learning and development. Applied Developmental Science, 24(2), 97-140. doi:https://doi.org/10.1080/10888691.2018.1537791

Dawson, G., Ashman, S. B., \& Carver, A. J. (2000). The role of early experience in shaping behavioral and brain development and its implications for social policy. Development and Psychopathology, 12, 695-712.

Gardner, H. E. (2011). Frames of mind: the theory of multiple intelligences. New York : Basic Books; 3rd Edition (March 29, 2011).

González, L., Cortés-Sancho, R., Murcia, M., Ballester, F., Rebagliato, M., \& Rodríguez-Bernal, C. L. (2020). The role of parental social class, education and unemployment on child cognitive developmentEl rol de la clase social, la educación y el desempleo parentales en el desarrollo cognitivo infantil. Gaceta Sanitaria, 34(1), 51-60. doi:https://doi.org/10.1016/j.gaceta.2018.07.014

Haditono, \& Rahayu, S. (2011). Developmental psychology. Yogyakarta: Gadjah Mada University Press. .

Halim, L., Rahman, N. A., Zamri, R., \& Mohtar, L. (2018). The roles of parents in cultivating children's interest towards science learning and careers. Kasetsart Journal of Social Sciences, $\quad 39(2), \quad 190-196$ doi:https://doi.org/10.1016/j.kjss.2017.05.001

Hasbullah. (2013). Basics of Education. Jakarta: Rajawali Press.

Jin, X., Auyeung, B., \& Chevalier, N. (2020). External rewards and positive stimuli promote different cognitive control engagement strategies in children. Developmental Cognitive Neuroscience, 44, 100806. doi:https://doi.org/10.1016/j.dcn.2020.100806

Karibayeva, A., \& Bogar, Y. (2014). To what extent does parents' involvement in middle school influence children's educational progress? Procedia - Social and Behavioral Sciences, 152, 529-533. doi:10.1016/j.sbspro.2014.09.222

Kreiner, C. T., \& Sievertsen, H. H. (2020). Neonatal health of parents and cognitive development of children. Journal of Health Economics, 69, 102247. doi:https://doi.org/10.1016/j.jhealeco.2019.102247

Musfiroh, T. (2012). pengembangan kecerdasan majemuk. Tangerang: Universitas Terbuka.

Nur, I. R., Herman, T., \& Mariyana, R. (2018). Logical-mathematics intellegence in early childhood students. International Journal of Social Science and Humanity, 8(4), 105-109. doi: 10.18178/ijssh.2018.8.4.944

Papalia, O., \& Feldman. (2015). Human Development. Jakarta: Kencana.

Patrikakou, E. (2015). Relationships among parents, students, and teachers: The technology wild card. Procedia - Social and Behavioral Sciences, 174, 2253 - 2258. doi:10.1016/j.sbspro.2015.01.883

Purwanti, R., Suriansyah, A., Aslamiah, A., \& Dalle, J. (2018). Introducing language aspect (English) to early childhood through the combination of picture and picture model, talking stick model, flashcard media, and movement and song method in B1 group at Matahariku bilingual kindergarten Landasan Ulin Tengah . European Journal of Education Studies, 5(7), 26-34.

Riyanti, H., Suciati, \& Karyanto, P. (2018). Enhancing students' logical-thinking ability in natural science learning with generative learning model. Biosaintifika Journal of Biology \& Biology Education, 10(3), 648-654. doi:http://dx.doi.org/10.15294/biosaintifika.v10i3.1661 2

Rohmah, N., \& Waluyo, E. (2014). Arithmetic dice media as counting concept introduction media in early childhood setting. Indonesian Journal of Early Childhood Education Studies, 3(2), 127-133. doi:10.15294/ijeces.v3i2.9486

Su, M., Schotten, M. T., Zhao, J., Song, S., Zhou, W., Gong, G., McBride, C., Tardif, T.,Ramus, F., \& Shu, H. (2020). Influences of the early family environment and long-term vocabulary development on the structure of white matter pathways: A longitudinal investigation. Developmental Cognitive Neuroscience, 42, 100767. doi:https://doi.org/10.1016/j.dcn.2020.100767

Sujiono, Y. (2013). Basic concepts of early childhood education. Jakarta: PT. Indeks. 
Suriansyah, A., Aslamiah, Noorhafizah, \& Sulaiman. (2009). Strategi pembelajaran. Banjarmasin: Universitas Lambung Mangkurat.

Susanto, A. (2015). Learning theory and learning in primary schools. Jakarta: Kencana Prenadamedia Group.

Sutcliffe, J. (2012). Baby bonding: Forming an inner bond with the baby. Jakarta: Taramedia dan Restu Agung.

Suwarjo, \& Eliasa. (2011). 55 Games (games) in guidance and counseling. Yogyakarta: Paramitra Pulishing.

Tierney, A. L., \& Nelson, C. A. (2009). Brain development and the role of experience in the early years. Zero to Three, 9-13.

Wahyudi, M. D. (2015). Implementasi authentic assessment di PAUD. Prosiding SEMNAS PS2DMP ULM. 1, pp. 17-26. Banjarmasin: rumahjurnal.net.
Wang, Y., \& Chiew, V. (2010). On the cognitive process of human problem solving. Cognitive Systems Research, 11(1), 81-92. doi:https://doi.org/10.1016/j.cogsys.2008.08.003

Wang, Z., \& Wang, L. (2015). Cognitive Development: Child Education. In International Encyclopedia of the Social \& Behavioral Sciences (pp. 38-42). London: Elsevier.

Wulandari, B., \& Surjono, H. D. (2013). Pengaruh problem-based learning terhadap hasil belajar ditinjau dari motivasi belajar PLC di SMK. Jurnal Pendidikan Vokasi, 3(2), 178191.

Yilmaz, Z. (2017). Young children's number sense development: Age related complexity acrosscases of three children. International Electronic Journal of Elementary Education, 9(4), 891-902. 